\title{
Reading Habits of Senior Secondary Students at Ujjain City, M.P. (INDIA)
}

\author{
Sapna Mishra \\ (Lecturer,Persuing Ph.D) Mayadevi Iinstitute of Advanced Education Dewas,(M.P.)
}

\begin{abstract}
Abstact: This is a report on reading survey carried out among the Senior secondary students at ujjain city M.P.. The Present study explore the reading habits of senior secondary studentsin ujjain city This study shows that the various aspects reading habits like aims of the study, reading materials borrowed fromlibrary, time spent in library, use reference materials, which medium reading material preferred by students,place of reading, and to develop some suggesions for solution of the problems.suggesion have been given to make the service more like in the school libraries.
\end{abstract}

\section{Introduction}

The School library is the central force in the teaching and learning process. The school library exists to provide a range of learning opportunities for both large and small groups as well as individuals with a focus on intellectual content, information literacy, and the learner.In addition to classroom visits with collaborating teachers, the school library also serves as a place for students to do independent work, use computers, equipment and research materials; to host special events such as author visits and book clubs; and for tutoring and testing.One of the Major goals of the school library is to inspire a love for reading to promote a reading culture among its users. This implies the need to create the awareness of written letters, the need to read not only textbooks nut also to engage in creative, leisurely, and pleasurable reading (Segum 1995).

Reading is usually a private act, a personal ans individual relationship with a book, but then, it is the environment as long as it is favourable, which according to Gault (1982 p 16) encourage the setting up of this relationship. The school library must in this case serve as the needs environment. And this it should do, by integrating itself completely into the educational system to achieve the overall objectives of the school. And what, better ways are there to do this than to stimulate the intellectual growth of the child through the provision of appropriate instructional growth of the child through the provision of appropriate. It should go further by not transforming itself into a research centre of some sort where students are taught how to sift data through independent reading, but also by providing a workshop setting for supervised studies of individuals and groups.

\section{Previous Studies}

This paper presents a selective review of studies conducted indis and abroad, including Anderson (2007), Shahriza (2007), Train (2007), Bostrom \& lassen (2006), Corradini (2006), Dent (2006), Celep \& Cetin (2005), Brier \& Lebbin (2004), bit this type of research is unusual, since it studies the reading habit of the senior secondary students, Schools curriculum incorporates an expressive and exploratory from interactive education system, so that they develop an inquisitive mind and discover the power of self-determination and discipline to grow up into successful professionals and good human beings.

\section{Limitation of the study}

The present study is limited to the senior secondary belonging to five higher secondary schools i.e. Kendriya Vidayalaya,ujjain, oxford junior college, ujjain Public higher secondarySchool, St. Mary's Convent higher secondary school,Akshat international school .

\section{Objectives of the study}

The objectives of this study is to find out the mother tongue, motives of study, reading materials borrowed from library, time spent for the serious reading, use reference materials, languages, of newspaper that read daily, sections of newspapers read, place og reading, and to develop some suggestions for solution of the problem. This study will help to establish whether acquisition of intellectual skills.

\section{Methodology}

The study uses the case study method. A well structured questionnaire was designed and used for collecting data. The sample for the study was selected purposefully from those noticed in the school library more frequently. 400 questionnaires were distributed to the senior secondary students i.e. classXI\& XII. 75 
returned from Kendriya Vidyalaya, 72 Oxford Junior college, 70 returned fromUjjain Public higher scondary school, 70 returned from St. Mary's Convent higher secondary schoo, and 70, questionnaires returned fromAkshat international school, Therefore, a total of 357 questionnaires were returned and used for this study. The results of the findings were presented in tables using percentage.

\section{Data Analysis and discussion}

Table 1: sample size

\begin{tabular}{|l|l|l|l|l|}
\hline S.No & Name of the School & Class XI & ClassXII & Received Questionnaire \\
\hline 1 & Kendriya Vidyalaya & 30 & 45 & 75 \\
\hline 2 & oxford junior college & 35 & 37 & 72 \\
\hline 3 & ujjain Public higher secondarySchool, & 32 & 38 & 70 \\
\hline 4 & $\begin{array}{l}\text { St. Mary's Convent higher secondary } \\
\text { school, }\end{array}$ & 29 & 41 & 70 \\
\hline 5 & Akshat international school . & 27 & 43 & 70 \\
\hline Total & & 153 & 204 & 357 \\
\hline
\end{tabular}

Table 2: Mother Tongue

\begin{tabular}{|l|l|l|l|}
\hline S.No. & Mother Tongue & Responding Student & Percentage \% \\
\hline 1 & Hindi & 333 & 93.28 \\
\hline 2 & English & 24 & 90.72 \\
\hline Total & & 357 & 100 \\
\hline
\end{tabular}

The Table 2 show that the $93.28 \%$ students mother tongue were as Hindi, whereas $9.72 \%$ as mother tongue English.

Table3: Aims of Reading

\begin{tabular}{|l|l|l|l|}
\hline S.No. & Access the Information & No. of Students & Percentage \% \\
\hline 1 & To get Information & 167 & 46.78 \\
\hline 2 & To derive pleasur & 28 & 7.84 \\
\hline 3 & $\begin{array}{l}\text { To improve my general } \\
\text { knowledge }\end{array}$ & 136 & 38.09 \\
\hline 4 & it is my hobby & 26 & 7.28 \\
\hline Total & & 357 & 100 \\
\hline
\end{tabular}

Table 3 show that $46.78 \%$ students were read the books newspaper \& magazines for getting the information, $38.09 \%$ students to improve the general knowledge, $7.84 \%$ to derive pleasure, and $12 \%$ says its hobby.

Table 4: Time spent for reading

\begin{tabular}{|l|l|l|l|}
\hline S.No. & Time spent for reading & No. of Students & Percentage \% \\
\hline 1 & 1 to 2 hours & 33 & 9.24 \\
\hline 2 & 2 to 3 hours & 73 & 20.45 \\
\hline 3 & 3 to 4 hours & 187 & 52.38 \\
\hline 4 & 5 hours and above & 64 & 17.93 \\
\hline Total & & 357 & 100 \\
\hline
\end{tabular}

Table 4 shows that most of the students study 3 to 4 hours daily.

Table 5: Are you borrow reading material from library

\begin{tabular}{|l|l|l|l|}
\hline S.No. & Books borrow from library & No. of Students & Percentage \% \\
\hline 1 & Yes & 327 & 91.59 \\
\hline 2 & No & 30 & 8.41 \\
\hline Total & & 357 & 100 \\
\hline
\end{tabular}

Table 5 shows that $91.59 \%$ of students borrowed reading materials from library.

Table 6: Kinds books borrow from library

\begin{tabular}{|l|l|l|l|}
\hline S.No. & $\begin{array}{l}\text { Kinds Books borrow from } \\
\text { library }\end{array}$ & No. of Students & Percentage \% \\
\hline 1 & By Subject & 285 & 78.83 \\
\hline 2 & Recreational & 72 & 20.17 \\
\hline Total & & 357 & 100 \\
\hline
\end{tabular}

Table 6 shows that $78,83 \%$ of the students were borrowed reading materials from library related to their subjects, whereas $20.17 \%$ students were borrowed reading materials from library like recreational materials. 
Table 7: language of reading material do you read

\begin{tabular}{|l|l|l|l|}
\hline S.No. & Language & No. of Students & Percentage $\%$ \\
\hline 1 & English & 230 & 64.42 \\
\hline 2 & Hindi & 246 & 68.90 \\
\hline 3 & others & 19 & 5.32 \\
\hline Total & & 357 & 100 \\
\hline
\end{tabular}

(Multiple answers allowed)

Table 7 shows that $64.42 \%$ of students were used as English languages for study, whereas $68.90 \%$, as Hindi, followed by $5.342 \%$ students were used other languages.

Table 8: use of reference material.

\begin{tabular}{|l|l|l|l|}
\hline S.No. & Reference material & No. of Students & Percentage $\%$ \\
\hline 1 & Encyclopedias & 183 & 51.26 \\
\hline 2 & Dictionaries & 228 & 63.86 \\
\hline 3 & Maps, Globes & 61 & 17.09 \\
\hline 4 & Year Books & 173 & 48.46 \\
\hline Total & & 357 & 100 \\
\hline
\end{tabular}

(Multiple answers allowed

Table 8 shows that $63.86 \%$ of students were used reference materials like dictionaries, $51.26 \%$ encyclopedias, $48.46 \%$ year books, whereas $17,09 \%$ used maps, globes.

Table 9: Read News paper daily.

\begin{tabular}{|l|l|l|l|}
\hline S.No. & News Paper & No. of Students & Percentage \% \\
\hline 1 & English & 317 & 88.79 \\
\hline 2 & Hindi & 192 & 68.90 \\
\hline Total & & 357 & 100 \\
\hline
\end{tabular}

(Multiple answers allowed)

Table 9 shows that $88.79 \%$ of students were read English newspaper daily, while $68.79 \%$ read Hindi newspapers.

Table 10: Which section of newspaper like most.

\begin{tabular}{|l|l|c|c|}
\hline S.N. & Newspaper Section & No. of Students & Percentage \% \\
\hline 1. & Advertisement & 34 & 9.52 \\
\hline 2. & Editorial & 24 & 6.72 \\
\hline 3. & Cinema News & 47 & 13.16 \\
\hline 4. & Letter to editors & 09 & 2.52 \\
\hline 5. & politics & 64 & 17.92 \\
\hline 6. & Sensational News & 63 & 17.65 \\
\hline 7. & Sport & 116 & 32.49 \\
\hline Total & & 357 & 100 \\
\hline
\end{tabular}

Table 10 Shows that $32.49 \%$ of students were like most sections of newspaper i.e. sport news, $7.92 \%$ political news, $17.65 \%$ sensational news, $13.16 \%$ cinema news, $9.52 \%$ advertisement, and $6.72 \%$ read editorial, The least number of users i.e. $2.52 \%$ like letters to the editors.

Table 11: Read Magzines.

\begin{tabular}{|c|l|c|c|}
\hline S.N. & Magazines & $\begin{array}{c}\text { No. of } \\
\text { students }\end{array}$ & Percentage \% \\
\hline 1. & Reader digest & 230 & 64.42 \\
\hline 2. & Film Magazine & 71 & 19.89 \\
\hline 3. & india Today & 111 & 31.09 \\
\hline 4. & outlook & 87 & 24.37 \\
\hline 5. & Mathematics Today & 95 & 26.61 \\
\hline 6. & Competition Success Review & 218 & 61.06 \\
\hline 7. & Blitz & 118 & 33.05 \\
\hline 8. & Science Today & 89 & 24.92 \\
\hline 9. & Science Reporter & 89 & 27.45 \\
\hline 10. & Chemistry Today & 90 & 25.21 \\
\hline 11. & Physics Today & 110 & 30.81 \\
\hline 12. & Biology Today & 103 & 28.85 \\
\hline 13. & Cricket Today & 97 & 27.17 \\
\hline 14. & Sports Today & 59 & 16.52 \\
\hline 15. & PC Quest & 51 & 14.28 \\
\hline
\end{tabular}

(Multiple answers allowed) 
Table 11 shows that $64.42 \%$ students were read magazine like reader digest, $61.06 \%$ competition success review, $33.05 \%$ blitz,31.09\% india today, 30.81\% physics today, 28,.85\% biology today, $27.45 \%$ science reporter, $27,17 \%$ cricket today, $26,61 \%$ mathematics today, $25,21 \%$ chemistry today, $24.92 \%$ science today, $24,27 \%$ outlook, $19,89 \%$ film magazines, and 16,52\% sports today. The least number of students were read magazine like pc quest i.e. $14.28 \%$.

Table 12: Reading Place

\begin{tabular}{|l|l|l|l|}
\hline S.No. & Reading Place & No. of Students & Percentage \% \\
\hline 1 & Home & 174 & 48.74 \\
\hline 2 & School library & 135 & 37.81 \\
\hline 3 & The Public/Local library & 48 & 13.44 \\
\hline Total & & 357 & 100 \\
\hline
\end{tabular}

Table 12 shows that $48.74 \%$ students were read at home, $37.81 \%$ in school library, whereas $13.44 \%$ students were read at public/local library.

Table 13: Source of getting Reading materials.

\begin{tabular}{|l|l|l|l|}
\hline S.No. & Source of getting books & No. of Students & Percentage \% \\
\hline 1 & School library & 214 & 59.94 \\
\hline 2 & Friends & 48 & 37.81 \\
\hline 3 & Home & 68 & 19.05 \\
\hline 4 & The Public/Local library & 27 & 13.44 \\
\hline Total & & 357 & 100 \\
\hline
\end{tabular}

Table 13 revealed that $59.94 \%$ of students their source of getting books were the school library, $37.81 \%$ from friends, $19.05 \%$ home, and $13.44 \%$ public library. Thus the majority of the respondents sources of getting information about books from school library.

Table 14: Source of getting Newspaper and magzines

\begin{tabular}{|l|l|l|l|}
\hline S.No. & Source of getting magzines and newspaper & No. of Students & Percentage \% \\
\hline 1 & Individual subscription & 198 & 55.46 \\
\hline 2 & Friends & 24 & 6.72 \\
\hline 3 & School library & 135 & 37.81 \\
\hline 4 & The Public/Local library & 23 & 6.44 \\
\hline Total & & 357 & 100 \\
\hline
\end{tabular}

Table 14 shows that for $5546 \%$ students sources of getting the newspaper and magazines were the individual subscription, $37,81 \%$ school library, $6.71 \%$ friends and $6.44 \%$ getting from public/Local library.

\section{Findings of the Study}

The result of the present study revealed that a majority of the students mother tongue is Hindi.

The result of the present study revealed that a majority of the students their reading motives is getting the information, and to improve the general knowledge.

The result of the present study revealed that a large majority of the students study between 3 to 4 hours daily.

The result of the resent study revealed that most of the students borrow reading materials from their school library.

The result of the present study revealed that a large majority of the students reading materials related to their subjects.

The result of the present study revealed that most of the students proffered reading materials in Hindi and English languages.

The present study most of the students used reference materials like dictionary as well as encyclopaedia.

The result of the present study revealed that a majority of the students reading newspapers daily published in English as well as Hindi.

The present study revealed that most of the students like sports sections of the newspapers daily.

A large number of students are reading magazines like reader digest and competition success review.

The result of the present study revealed that a majority of the students reading place are their home, and school library.

The result of the present study recealed that most of the students getting reading materials from their school library. 
The result of the present study recealed that a majority of students getting newspaper, and magazines by individual subscription.

\section{Conclusion and suggestions}

The above findings of this study lead us to conclude that senior secondary students needs to improve their reading habits. It will be beneficial to have a record of their reading habits in order to make predictions about their scademic success in the study. For effective promation of reading habits, skills and culture, reading must be made pleasurable and voluntary. All shades of opinion must be catered for be well considered. It is such a demonstration of democratic sensitivity that can turn even a reluctant reader to a lover of books. In library there should be adequate reading area and related facilities to accelerate reading habits. There are still barriers to creating a reading environment that will inculcate good reading habits in senior secondary school students. The library us still the best place for quiet study. A serious senior secondary student should give priority to studying in the library. Library periods should be include in the time table Book-discssion -clubs may be encourages in each school. If a group of students reads books and meets weekly to discuss the books they have read, thet may find a new sort of fellowship and they will able to speak intelligently not only about books, but also about all problems. So book club in each school may be encouraged by the authorities in order to cultive healthy reading habits among students. The production of reading materials with indinal background for cultural reading should be encouraged so as to enable student $s$ to know the greatness of our rich culture and civilization. The findings of this survey lead us to conclude the senior secondary students need to improve their reading habits. It will be beneficial to have a record of their reading habits in reder to make predictions about their academic success in the academic programme. Both librarians and other course lecturers concur that generally their expectations of their student's reading ability, have not been met. It would be helpful to librarians to have a heightened awareness of the reading difficulties faced by our students. One of the steps taken to minimize reading problems would be to incorporate study skills components within the courses or to make reading lists (in particular literature texts) more manageable. This activity can assist in the promotion of autonomous learning and make students more independent and resourceful.

\section{References}

[1]. Andeerson, Karen. "Education and Training for Records Professinals." Records Management Journal 17.2 (2007): 94-106.

[2]. Apeji, E. Adeche. "Developing Reading Habits and Skills in Schools." Library Herald 47.1 (2009): 15-22.

[3]. Bostrom, Lena and Lassen, Liv M. "Unraveling Learning, Learning Styles, Learning Strategies and Meta-Cognition." Education + Training 28.2/3 (2006): 178-89.

[4]. Brier, David J and Lebbin, Vickery Kaye. "Teaching Information Literacy Using the Short Story. Reference Service Review 32.4 (2004): 383-87.

[5]. Gallik,J.D. "Do they Read of pleasure ?Recreational reading habits of college students."Journal of adolscent and adult literacy.42.6(1990):480.

[6]. Lgun,Stella E and adogbeji,ogenewopaga Benson. . "Study habits of Postgraduate students in selected Nigerian university ." Library Philosphy and Practice (e-Journals)Annual volume , November 2007.

[7]. Zaki, N. (1991). User education in Nigeria university: The need for new approaches. International Library Movement, 13(1): 27-43. 